\title{
PREVENTION OF OFFENCES IN THE SPHERE OF VALUE ADDED TAX ADMINISTRATION
}

\begin{abstract}
In the article the author explored the legal regulation of counteraction to VAT evasion (avoidance by taxpayers of their tax liability by minimizing tax liabilities), which is a specific type of activity of tax authorities. The continuous development of public relations in the field of taxation in Ukraine requires effective application of administrative prevention (counteraction) measures in this area and, of course, the qualitative state of legal regulation of these measures. In the legal literature, administrative prevention measures were mainly studied in terms of conceptual and categorical apparatus and their classification. To date, considering the introduction of electronic administration of value added tax, studies on the use of administrative prevention measures by public authorities in the scientific field have not been analyzed. Taking into account international experience and based on a systematic analysis of the current legislation, the author deals with the legal mechanism for counteracting evasion from paying value added tax by means of introducing electronic administration of value added tax. The author notes that with the introduction of automated monitoring of risk assessment (taking into consideration the criterion of the amount of paid value added tax) (the so-called "tax burden" and/or "tax return"), the state is trying to increase budget revenues. The author concludes that administrative prevention (counteraction) measures used by regulatory authorities, in a sense, are the tools by which it is possible to achieve timely response to the activities of taxpayers aimed at tax evasion. It was substantiated that automated monitoring of compliance of tax invoices with the risk assessment criteria can be considered as a preventive measure, according to which taxpayers transactions aimed at forming an illegal tax credit are detected by regulatory authorities. In turn, making decisions if a payer of value added tax meets the Criteria of being a risky payer, and accordingly, further suspension (blocking) of registration of tax invoices of the specified payer, is a measure to counteract evasion from paying value added tax. It was proved that from the legal point of view, the legal mechanism of administrative prevention (counteraction) measures, in particular, those regarding the implementation (conducting) of automated monitoring, should contribute to the avoidance of legal collisions and contradictions that arise between regulatory authorities and taxpayers.
\end{abstract}

Key words: measures of administrative prevention, value added tax (VAT), system of electronic VAT administration, automated monitoring of risk assessment criteria, measures of administrative prevention (counteraction). 


\section{Andrii Lohvyn,}

Ph.D. in Law orcid.org/0000-0003-4373-375X logvin.andrey80@gmail.com

\section{Introduction}

Measures of administrative prevention create the necessary conditions for strict compliance with tax legislation, detection and termination of tax offenses and prevent possible harmful consequences from their commission, which contributes to legality and law enforcement in the field of taxation. Counteracting the evasion from paying value added tax (hereinafter referred to as VAT) (avoidance of tax obligation by taxpayers through minimizing tax liabilities, manipulating reporting, forming illegal "fictitious" tax credit, unlawful reimbursement, etc.) is a specific activity of the State Tax Service bodies (hereinafter referred to as the STS bodies, controlling bodies) in the field of taxation, to which special attention is paid and which includes the system of appropriate measures. Constant development of social relations in the taxation sphere in Ukraine, in particular, introduction of electronic administration of value added tax (hereinafter referred to as CEA of VAT), requires effective application of measures of administrative prevention (counteraction) of offenses in this area and, of course, the qualitative state of legal regulation of these measures.

The specified measures include the introduction of monitoring of compliance of tax invoices/adjustment calculations with the criteria for assessing the degree of risks sufficient to stop the registration of the VAT invoice/adjustment calculation in the Unified Register of Tax Invoices.

In the law literature, measures of administrative prevention were mostly studied in terms of the notion-category apparatus and their classification. At present, taking into account the introduction of CEA of VAT, the issues of application of the measures of administrative prevention by entities of power in the scientific sphere were not studied.

In the article, the legal mechanism for counteracting VAT evasion was explored, taking into account the introduction of electronic VAT administration and monitoring the compliance of VAT invoices/adjustment calculations with the criteria for assessing the degree of risks, and the relevant conclusions were made based on systemic analysis of the norms of the current legislation. 


\section{Measured of administrative prevention}

Measures of administrative prevention belong to the most common among all measures of administrative compulsion, the application of which is provided by the norms of tax legislation. Measures of administrative prevention are often referred to in administrative law as administrative and preventive measures, as they are used to prevent offences if they are only possible (Kolpakov, 2004, p. 279).

The purpose of their application is protection of the interests of the state economic security and prevention of committing offenses, that is, these measures have a clear preventive orientation. Application of administrative and preventive measures in the field of taxation has its own characteristics, which are determined by the imperative nature of legal relations in this area (Matselik, 2005, p. 10).

Some researchers point out that the purpose of application of these measures is to prevent tax offences and control correctness of the relevant payments made by taxpayers to the state budget (Golovach, 2004, p. 11). They are different in volume and orientation of their application, different in terms of their normative regulation.

In theory of administrative law, the scientists proposed several classifications of measures of administrative compulsion. For example, such scientists as O. Bandurka, Y. Bytiak, S. Goncharuk, S. Kivalov, A. Komziuk support the classification of administrative compulsion measures into administrative prevention measures, administrative discontinuation measures and administrative penalties, proposed by M. Yeropkin (Bandurka, 2004). Instead, I. Galagan separates the measures of administrative liability, suspension and prevention (Bytiak, 2005). I. Holosnichenko and B. Rosynskyi consider them a kind of measures of administrative discontinuation, because they are used after the beginning of an offense in order to stop it (Holosnichenko, 2007).

In our opinion, each of the positions has its point. Just note that for administrative compulsion in the system of measures of counteraction of value added tax evasion (minimization of tax liabilities, manipulation of reporting, etc.), measures of administrative prevention and counteraction are most characteristic. That is why it is more logical to discuss the activities of regulatory authorities as measures of administrative prevention (counteraction) of value added tax evasion (hereinafter referred to as VAT).

It should be emphasized that the etymological meanings of the terms "prevention" and "counteraction" are different: the former means "averting something undesirable (negative phenomenon, process) in advance", and the latter means "an action directed against another action, counteracting it" (Worldwide dictionary of the Ukrainian). However, in our opinion, it is logical to unite them in terms of the activities of regulatory authorities, which consists not only in the prediction (prevention) of negative phenomena in the field of tax collection, but also in counteracting existing negative phenomena, or those that may occur.

An important component, which contributes to the effectiveness of the application of measures of administrative prevention and constructive content, taking into 
account their compliance with modern tax relations, which are rapidly developing, is monitoring possible risks during collection of taxes and fees (available information in the information systems of the STS bodies, the implementation of which encourages a detailed analysis of the possible consequences of tax administration (achieving positive results and receipt of funds to the State Budget) and, accordingly, averting (prevention and counteraction), in particular, VAT (minimization of tax liabilities, manipulation of reporting, formation of illegal "dubious" tax credit, illegal reimbursement, etc.).

The term "monitoring" is most often used in the sense of constant observation (supervision) of any process. The above did not avoid the process of VAT collection, in particular, prevention of facts of minimization (optimization) of tax liabilities, evasion from paying by manipulation of tax reporting, illegal VAT refund.

At the same time, from the legal point of view, its legal mechanism should contribute to avoidance of legal collisions and contradictions that arise between regulatory authorities and taxpayers. This, in turn, provides (stipulates) the need to optimize the relevant legal norms of the national legislation, in particular, a clear and understandable statement of the provisions of normative legal acts, exclusion of ambiguous (plural) interpretation, duplication, etc.

\section{International experience}

It will be appropriate to outline the experience of some European countries regarding preventive measures. For example, Irish tax controlling bodies selectively visit taxpayers, the results of the visits are compared with the registration data and other information, and the tax authorities of Great Britain and Lithuania have the power to receive additional information from a taxpayer if the registration application of a VAT payer contains dubious data. In Sweden, information received from third parties is used (Andriushchenko, 2015).

Taking into account international experience, prevention of cases of non-payment of VAT, avoidance of fictitious reimbursement, determining risky taxpayers during the procedure of their registration by value added tax payers as one of the possible means of combating this problem, is the norm for many European countries mentioned above. At the same time, it should be noted that programs such as Fiscalis (The Fiscalis 2020 Programme) and VIES (VAT Information Exchange System) enquiries are used to counteract offences in the VAT sphere (tax fraud) in the EU. The specified programs allow national tax administrations to create and share information and experience. But risk monitoring, such as the one used in Ukraine, is not performed by them.

\section{Automated risk monitoring}

Starting from July 2017, taking into account the requirements of the Tax Code of Ukraine (Law of Ukraine No. 2755-VI, 2010), a system for monitoring the compliance of VAT invoices/adjustment calculations with the criteria for assessing 
the degree of risks sufficient to stop the registration of a VAT invoice/adjustment calculation in the Unified Register of Tax Invoices (hereinafter referred to as SM of CRA, System) for VAT payers in Ukraine.

According to the new provisions of the tax legislation, "risky and questionable" operations should be detected and suspended at the stage of registration of tax invoices to the Unified Register of Tax Invoices (hereinafter referred to as the URTI), while real operations must be registered without any complications. In fact, this specified System became a part of the system of electronic VAT administration.

At the same time, taking into account numerous complaints (which were also mentioned in the relevant publications of the author) of the work of SM of CRA (imperfect normative regulation of the System's operation; taking into account the indicators of acquisition and implementation exclusively since 01.01.2017; non-consideration of the specifics of the work of taxpayers-producers; the grounds for deciding to refuse to register a tax invoice/adjustment calculation did not meet the criteria for distinction and clarity of the act of individual action, etc.), as a result of a joint meeting of the Ministry of Finance of Ukraine, the Committee on Taxation and Customs Policy of the Verkhovna Rada of Ukraine, the State Fiscal Service of Ukraine (hereinafter referred to as the SFS of Ukraine, the SFS), business representatives and experts regarding the changes in the work of the system of value added tax risks, the joint decision to suspend the work of the SM of CRA was made. It was decided to develop further the accepted solution that will not carry significant risks for all segments of business and at the same time will be an effective tool for combating VAT embezzlement schemes, and the introduced amendments will be aimed at solving the challenges faced by business due to the gaps in the implementation and design of the system.

In this regard, the work of the SM ofCRA was suspended from 02.01.2018 and fully resumed from 22.03.2018, given the approval by the Cabinet of Ministers of Ukraine of the Procedure for stopping the registration of the tax invoice/adjustment calculation in the URTI; Procedure for working of the commissions that made decisions on registration of a VAT invoice/adjustment calculation in the URTI or refusal in such registration; Procedure for consideration of complaints against resolutions of regional commissions that decide on registration of a VAT invoice/adjustment calculation in the Unified Register or refusal in such registration (hereinafter referred to as Resolution No. 117) (Resolution of the Cabinet of Ministers of Ukraine No. 117, 2018). The key changes should include the fact that the decision on registration of a VAT invoice/adjustment calculation or refusal to register is taken by the Regional Commission (regional bodies of the SFS), until that time the decisions were made exclusively by the SFS Commission.

At present (from 01.02.2020), the issue of monitoring the compliance of tax invoices/adjustment calculations with the criteria for assessing the degree of risks, sufficient to stop the registration of a tax invoice/adjustment calculation in the Unified Register are regulated by the Resolution of the Cabinet of Ministers of Ukraine 
on approval of the procedure for stopping the registration of VAT invoices/adjustment calculations in the Unified Register (Resolution of the Cabinet of Ministers of Ukraine No. 1165, 2019) and by the Order of the Ministry of Finance of Ukraine On Approval of the Procedure for Making Decisions on Registration/Refusal to Register Tax Invoices/Adjustment Calculations in the Unified Register (Order of Ministry of finance of Ukraine No. 520, 2019). These documents approved the new Criteria for risk of a value-added tax payer (hereinafter referred to as the Criteria for risk of tax payers) and the Criteria for risk of operations (hereinafter referred to as the Criteria for risk of operations), the list of indicators, which determine the positive tax history of a taxpayer and the form of a decision on registration/refusal to register tax invoices/adjustment calculations in the URTI.

Significant changes include a change in the algorithm of automated monitoring, according to which tax invoices/adjustment calculations are not subject to monitoring, in particular, an increase in the criterion for the total amount of VAT (except for the amount of VAT paid during the import of goods into the customs territory of Ukraine), paid for the last 12 calendar months, which should be more than UAH 1 million. Until now, the cut-off feature of the amount of tax paid was UAH 400 thousand.

According to the definition contained in Resolution No. 117 (Resolution of the Cabinet of Ministers of Ukraine No. 117, 2018), monitoring is a totality of measures and methods of work of regulatory authorities, which reveals the results of analysis of available information in the information resources of the SFS and/or the objective features of existence of risks of tax legislation violation by the results of processing and analysis of tax information.

At the same time, there is no concept of "monitoring" in Resolution No. 1165 (Resolution of the Cabinet of Ministers of Ukraine No. 1165, 2019). However, it contains the definition of such concept as automated monitoring of compliance of a tax invoice/ adjustment calculation with the criteria for assessing the degree of risks as a totality of measures and methods used by the regulatory authority to identify the features of risks of violation of tax legislation according to the results of automated analysis of the tax information available in the information systems of the controlling bodies.

As one can see, the activities of the regulatory authorities are aimed at overcoming the negative phenomena, related to VAT evasion (minimization of tax liabilities, manipulation of reporting, formation of an illegal "dubious" tax credit, illegal reimbursement, etc.), within which they perform automated monitoring of compliance of tax invoices/adjustment calculations with the criteria for assessing the degree of risks sufficient to stop the registration of a tax invoice/adjustment calculation in the Unified Register, which is a measure of administrative prevention (counteraction).

In turn, it should be emphasized that automated monitoring of compliance of VAT invoices/adjustment calculations with the criteria for assessing the degree of risks is a measure of administrative prevention aimed at preventing (counteracting) the evasion of paying value added tax, which is not sufficiently regulated from a legal point of view. The above enables the regulatory authorities at their own discretion to 
resolve the issue of riskiness of a taxpayer and riskiness of operations, and allows non-conscientious taxpayers to manipulate existing documents.

In this case, it should be noted that there is no distinct algorithm that would make it possible to determine whether it is true that:

- a specific operation related to determining the tax liabilities and tax credit of VAT (implies drawing up a vat invoice), is aimed at distributing illegal "dubious" tax credit, that is, is illegal;

- a taxpayer is risky (making a decision on compliance of a VAT payer with the Criteria of riskiness of a taxpayer and his inclusion in the corresponding list).

Currently determined (as of 01.01.2021) Criteria of riskiness of a payer (points 1-8) (Resolution of the Cabinet of Ministers of Ukraine No. 1165, 2019) do not provide an answer to these questions.

Thus, regarding the Criteria of riskiness of a payer (points 1-4) (Resolution of the Cabinet of Ministers of Ukraine No. 1165, 2019), which are determined based on the relevant information (available in the controlling bodies, provided by the founders and/or managers), it would be appropriate to clearly determine the sources of origin of such information (existence of instituted proceedings; court verdicts).

The feature "regulatory authorities have available tax information, which became known in the process of conducting current activities during implementation of tasks and functions assigned to the regulatory authorities, that determines the riskiness of a business transaction specified in the VAT invoiceladjustment calculation submitted for registration" enables the controlling authority at its own discretion to enter almost any tax payer into the list of risky ones, since it does not contain specifications, in particular, regarding the source of obtaining such tax information (a list of what can be considered such information) and grounds to consider an operation risky. Moreover, this gives reason to consider the existence of non-automatic monitoring, but rather manual management of blocking of registration of tax invoices.

At the same time, in our opinion, the Criteria for riskiness of a taxpayer cannot each separately indicate the riskiness of a taxpayer, so the riskiness of a taxpayer should be determined by the aggregated performance or aggregated characteristics. It is necessary to specify in the normative document the features, in which the controlling body can: decide on compliance of a payer of value added tax with the Criteria of riskiness of a payer; to determine a business operation as risky.

As you can see, not only illegal transactions of "risky" taxpayers, but also completely legitimate activities of conscientious taxpayers fall under the specified criteria. These circumstances create, firstly, the obstacles for conscientious taxpayers, and secondly, the opportunity for non-conscientious taxpayers to manipulate existing documents, and, accordingly, to further evade paying VAT.

Regarding the Criteria of riskiness of an operation (Resolution of the Cabinet of Ministers of Ukraine No. 1165, 2019), it will be appropriate to note the following. The Criteria of riskiness of an operation under point 1 (relative to tax invoices) 
and under point 5 (regarding adjustment calculations) have content differences regarding the conditions of comparison with the data in the URTI, since during the registration of tax invoices, monitoring is carried out by the volume of purchase and sale (in quantitative terms) and with the use of coefficient of 1.5, and during the registration of adjustment calculations, monitoring is carried out by the amount of compensation of the cost of goods/services. That is, in this case (regarding adjustment calculations) it does not take into account the specifics of any economic activity related to the purchase and sale of goods (existence of added price), and accordingly, on the date of preparation of the adjustment calculation and its registration in the URTI, the system will compare not the volume of purchase and sale of a certain product, but rather its amount of purchase and the amount of sales (cost indicator that will be higher given the existence of added price).

In addition, it is necessary to pay attention that the criterion regarding the volume of purchase and sale concerns not only enterprises that manipulate tax reporting (mismatch of both volumes and assortment of purchased and sold goods), as well as enterprises that are engaged in production, or provide services, given that in the manufacture of products (performance of works, services) they purchase raw materials and materials, consume water, electricity, etc., that is, the codes of raw materials, goods under Ukrainian classifier of goods of foreign economic activity and the services of the State classifier of products and services, which it purchases and manufactures, do not match.

Besides, in case of stopping registration of a VAT invoice, it allows submitting the same documents on purchases for various selling transactions to the Commission to consider.

It should be noted that even if the Commission takes into account the fact of the payer's submitting similar documents before (assessment of submitted documents on a particular transaction in the totality of the whole activity of a payer during a certain period) taking into consideration the informational capabilities of a controlling authority (analysis of available databases, etc.), this can already be regarded as the implementation of the tax control stipulated by the Tax Code (Law of Ukraine No. 2755-VI, 2010) (the type of which is information and analytical support of the activities of controlling bodies).

The above mentioned will not comply with the normative regulation of the issues of stopping the registration of the VAT invoice/adjustment calculation in the URTI, as they provide exclusively for the analysis of documents submitted for the decision to register a stopped VAT invoice (analysis of the relevant business transaction). That is, from the point of view of normative consolidation, the Commissions of the controlling body can study exclusively the transaction, for which a VAT invoice was drawn up and in respect of which a taxpayer submitted documents.

At the same time, we will pay attention to the fact that the decision will be made in view of the documents submitted by a taxpayer to confirm a business transaction (Order of Ministry of finance of Ukraine No. 520,2019). As you can see, the determined 
list contains the same documents on transportation confirmation (consignment invoices); quality passports, certificates of conformity; powers of attorney and others known from disputes over "worthless transactions" and "transactions not aimed at real occurrence of consequences". In fact, in case of stopping registration of a VAT invoice, the controlling body conducts inspections of certain business transactions.

It will be appropriate to note that if the normative document determines the need to submit such a list of documents to confirm a business transaction (that is, the procedure and method of proving the actual implementation of a business transaction), their submission is a prerequisite for making a relevant decision by the Commission.

At the same time, according to the current legislation, the lists of powers of attorney and invoices are not primary documents, and according to the sustainable judicial practice (Resolution of Supreme Court of Ukraine of 16 April 2019, case No. 804/5465/16), consignment notes are primary documents only to confirm transactions (provision of services) for the transportation of goods, and accordingly may not be provided to confirm business transactions. In this regard, in our opinion, they may not be included into the list. In addition, according to the sustainable practice of considering the cases by the Supreme Court of Ukraine, the existence or absence of certain documents, as well as some shortcomings in their registration, are not an indisputable basis for conclusions about non-existence of business transactions, if the movement of assets took place (Resolution of Supreme Court of Ukraine of 11 June 2019, case No. 825/2387/18; Resolution of Supreme Court of Ukraine of 28 August 2018, case No. 820/20188/14).

\section{Results}

Automated monitoring can be attributed to prevention measures, according to which the regulatory authorities detect transactions of taxpayers, aimed at the formation of illegal "dubious" tax credit (affects the minimization of tax liabilities and the formation of a negative VAT value, according to which budget refund can be obtained in future), and decision making on compliance of a payer of value added tax with the Criteria of riskiness of a payer and, accordingly, blocking the registration of tax invoices of these payers is a measure to counteract VAT evasion (stopping the distribution of illegal "dubious" tax credit).

With the introduction of automated monitoring of risk assessment (taking into account the criterion for the amount of VAT paid (the so-called "tax burden" or "tax return"), the state is trying to increase revenues to the budget. This also creates conditions for the use of schemes of manipulation of tax liabilities and tax credit by unscrupulous enterprises (adhering to certain conditions).

However, taking into account the available data on the number of decisions on refusal to register VAT invoices adopted during 2017-2018 (Report of the State fiscal service of Ukraine, 2017; Report of the State fiscal service of Ukraine, 2018) (information for 2019-2020 is not available), their appeal in administrative order (while a significant number of taxpayers may not use the procedure of administrative 
appeal, but immediately apply to the court for the protection of their rights), the results of consideration of such complaints, it is possible to say that this System led to an increase in the burden on both taxpayers and regulatory authorities.

At the same time, it is possible to state even now (taking into account the data of the Unified State Register of Court Decisions (Unified state register of court resolutions, 2020) that the monitoring system, taking into account the lack of proper normative regulation, led to an increase in tax disputes on appeal against resolutions (actions) of regulatory authorities, in particular, regarding refusal to register tax invoices, which in most cases are decided not in favour of the STS bodies, which affects the losses of the budget from payment (reimbursement) of court fees.

In addition, according to the reports on consideration of cases (the results of considerations according to the official website of the Judiciary power of Ukraine) in the order of administrative proceedings on the claims of taxpayers about cancellation of decisions of controlling bodies related to VAT collection, in 2017, the claims were satisfied in 2152 cases out of the total number of cases of 3012, on which the proceedings were completed (Report of courts of first instance about judicial examination of cases in order of administrative proceedings, 2017); in 2018, the claims were satisfied in 2628 cases out of the total number of 3895 cases, on which the proceedings were completed (Report of courts of first instance about judicial examination of cases in order of administrative proceedings, 2018); in 2019, the claims were satisfied in 2959 cases out of the total number of 4203 cases, on which the proceedings were completed Report of courts of first instance about judicial examination of cases in order of administrative proceedings, 2019).

\section{Discussion}

It should be noted that since the 1970s, weakening of work with taxpayers has led to conflict situations between governments and taxpayers. Thus, in the early $80 \mathrm{~s}$ of the twentieth century, the Canadian Tax Administration, strengthening enforcement measures on tax policy, tried to implement social and economic programs by reducing the costs of consulting and explanatory work with taxpayers. The U.S. Tax Office decided to reduce the level of servicing taxpayers in order to release costs and direct them to meet growing needs for implementing the programs of strengthening control and enforce tax collection measures. These decisions appeared not popular enough and drew criticism from the public. The situation was complicated with the introduction of unreliable systems of automated information processing, which, in turn, exacerbated the relations of the state and taxpayers. To solve the problem, attention to consulting and explanatory work among payers significantly increased, including considerable investments in computer and mathematical support of tax invoice processing systems (Protsenko, 2007).

In turn, Nobel laureate J. Stiglitz talks about the complexity of citizens' control over the actions of their own government. Tax authorities do not receive all the information from taxpayers, and the practice of tax avoidance is widely used by corporations. As a representative of the new paradigm, he distinguishes between 
five, as he points out, desired principles of organizing a reasonable tax system: economic efficiency, at which the tax system should not deny the effective allocation of resources; administrative simplicity - the tax system should be simple and relatively inexpensive; flexibility - quick reaction (in some cases automatic) to a change in parameters of economic development; political responsibility - the tax system must be built in such a way as to convince people that they pay taxes for a more complete and accurate reflection of their wishes by the political system; justice - the tax system should be fair in relevant approaches to different individuals - taxpayers. In a rapidly changing world, taxation flexibility is of particular importance (Taxation principles of Joseph Stiglitz).

Tax relations are among the most sensitive to changes in the economic basis in the whole system of legal relations. Accordingly, tax regulations should respond quickly and effectively to any changes in economic life in order, on the one hand, to eliminate the possible destructive impact of taxation on the economic development of the country, and on the other hand, not to miss out on the taxation objects, appearing in new forms from the tax conditions of the state (Stiglitz, 1997).

These circumstances provide for (stipulate) the need to optimize the relevant legal norms of national legislation, in particular, a clear and understandable statement of the provisions of regulations, the exclusion of ambiguous (multiple) interpretation, duplication, etc., as well as improvement of technical means (the use of certified software, which has passed the appropriate stages of industrial (experimental) implementation of analysis and processing tax reporting and tax invoices.

The world experience of organizing the activities of tax services shows that in order to ensure the fulfilment of their tasks, their work should be directed to two main directions - control over the implementation of tax legislation on timeliness and completeness of tax payments and clarification of their rights and obligations for taxpayers to assist in the implementation of the provisions of the current tax legislation (Protsenko, 2007).

At the same time, it is necessary to pay attention to Resolution No. (77)31 of the Cabinet of Ministers of the European Council on the protection of private persons related to the activities of administrative authorities (1977), which proclaims the principles the governments should be guided by in the formulation of their administrative procedures in respect of any individual measures or decisions that were taken during the implementation of public power in relations between a person (individual or legal entity) and administrative bodies. Citizens have the right to be listened to, and have the right to access information. They can also expect assistance and clarification from the authorities regarding the decisions taken, as well as indicate the available means of protection (Tymoshchuk, 2003, p. 460-468).

Taxpayers need more accurate and comprehensive rules to protect their rights, especially as the level of taxation increases, tax law becomes more complex and technical means are imperfect, new ways of obtaining and comparing information from different sources require appropriate processing. 
At the same time, the controlling authority should not be blamed on this matter (in some ways it is a hostage to the situation), since the adoption of relevant regulations is carried out by the Verkhovna Rada of Ukraine, the Cabinet of Ministers of Ukraine and the Ministry of Finance of Ukraine, and it is subject to the obligation to comply with the provisions of these normative legal acts, as well as control over their implementation by taxpayers. This affects the certain burden on the legal units of the controlling bodies (regional STS departments and STS of Ukraine) and units that are direct parts of the relevant Commissions and are related to the implementation of automated monitoring.

\section{Conclusions}

Thus, summing up the above:

1. Measures of administrative prevention (counteraction) used by regulatory authorities are in a sense the tools, by which the possibility of timely response to the activities of taxpayers aimed at tax evasion is achieved. Determining such instruments is logical, since the activity of the regulatory authorities is not only to foresee (prevent) negative phenomena in the field of tax collection, but also to counteract existing negative phenomena, or those that may emerge. At the same time, the first case is related to the prevention of possible offenses (tax evasion), which, in our opinion, is achieved both through preventive measures and at the expense of a qualitative legal framework (tax legislation), which regulates the taxation sphere (elimination of legal collisions, ambiguous interpretation). In the second case, efforts are directed to eliminate existing negative phenomena, or new ones that may arise in the future, taking into account the possibility of timely prevention, that is, creation of conditions, under which they will not be able to become widespread and their appropriate further elimination.

2. Automated monitoring is a part of the electronic administration of VAT and may be considered as a measure of prevention, according to which controlling bodies detect operations of taxpayers, aimed at forming an illegal "dubious" tax credit (affects the minimization of tax liabilities and the formation of a negative value of value added tax, according to which in the future budget refund may be received), and making a decision whether a taxpayer of value added tax meets the Criteria of riskiness of a payer and, accordingly, further suspension (blocking) of registration of tax invoices of these payers is a measure of counteracting the evasion of payment of value added tax (termination of distribution of illegal "dubious" tax credit).

3 . From the legal point of view, the legal mechanism of administrative prevention (counteraction) measures, in particular, those regarding automated monitoring, should contribute to the avoidance of legal collisions and contradictions that arise between regulatory authorities and taxpayers. It can be an effective means of tax control in order to prevent the schemes of manipulation of tax liabilities and tax credit, provided that there is proper legal basis. 


\section{Bibliography:}

1. Адміністративне право України : підручник / за заг. ред. О.М. Бандурки. Харків : Вид-во Нац. ун-ту внутр. справ, 2004. 480 с.

2. Адміністративне право України : підручник / Ю.П. Битяк, В.М. Гаращук, О.В. Дьяченко та ін. Київ : Юрінком Інтер, 2005. С. 170-202.

3. Адміністративна процедура та адміністративні послуги. Зарубіжний досвід i пропозиції для України / автор-упоряд. В.П. Тимошук. Київ : Факт, 2003. 496 с.

4. Андрющенко I.Є., Гринь Ю.В. Міжнародний досвід організації податкового адміністрування. Ефективна економіка. 2015. № 11. URL: http://nbuv.gov.ua/UJRN/ efek_2015_11_42 (дата звернення: 12.07.2017).

5. Всесвітній словник української мови. URL: https://uk.worldwidedictionary.org (дата звернення: 15.12.2020).

6. Головач А.В. Заходи адміністративного примусу, не пов'язані з відповідальністю, в діяльності органів державної податкової служби України: питання теорії та практики : автореф. дис. канд. юрид. наук : 12.00.07. Ірпінь : Нац. ун-т держ. податк. служби України, 2004. 19 c.

7. Голосніченко І.П. Перспективні положення кодифікації норм правового інституту адміністративної відповідальності. Право Украӥни. 2007. № 7. С. 60-63.

8. Єдиний державний реєстр судових рішень. URL: http://reyestr.court.gov.ua (дата звернення: 11.01.2021).

9. Звіт Державної фіскальної служби України за 2017. URL: http://sfs.gov.ua/data/ files/223549.PDF (дата звернення: 12.01.2021).

10. Звіт Державної фіскальної служби України за 2018. URL: http://sfs.gov.ua/data/ files/240396.pdf (дата звернення: 12.01.2021).

11. Звіт судів першої інстанції про розгляд справ у порядку адміністративного судочинства за 2017 рік (форма № 2-A). URL: https://court.gov.ua/inshe/sudova_statystyka/ rik_2017 (дата звернення: 14.12.2020).

12. Звіт судів першої інстанції про розгляд справ у порядку адміністративного судочинства за 2018 рік (форма № 1-A). URL: https://court.gov.ua/inshe/sudova_statystyka/ rik_2018 (дата звернення: 14.12.2020).

13. Звіт судів першої інстанції про розгляд справ у порядку адміністративного судочинства за 2019 рік (форма № 1-A). URL: https://court.gov.ua/inshe/sudova_statystyka/ rik_2019 (дата звернення: 14.12.2020).

14. Колпаков В.К. Адміністративно-деліктний правовий феномен : монографія. Київ : Юрінком Інтер, 2004. 528 с.

15. Мацелик Т.О. Адміністративний примус в діяльності органів державної податкової служби України : автореф. дис. ... ступеня канд. юрид. наук : 12.00.07 Ірпінь, 2005. 17 с.

16. Податковий кодекс України : Закон України від 02.12.2010 p. № 2755-VI. http:// zakon5.rada.gov.ua/laws/show/2755-17 URL: (дата звернення: 01.12.2020).

17. Податкові принципи Джозефа Стігліца. URL: https://pidruchniki.com/12041005/ finansi/podatkovi printsipi_dzhozefa stiglitsa (дата звернення: 12.12.2020).

18. Про затвердження порядків з питань зупинення реєстрації податкової накладної/ розрахунку коригування в Єдиному реєстрі податкових накладних : Постанова Кабінету Міністрів України від 21.02.2018 p. № 117. URL: https:/www.kmu.gov.ua/ua/npas/prozatverdzhennya-poryadkiv-z-pitan-75 (дата звернення: 12.01.2021).

19. Про затвердження порядків з питань зупинення реєстрації податкової накладної/ розрахунку коригування в Сдиному реєстрі податкових накладних : Постанова Кабінету Міністрів України від 11.12.2019 р. № 1165. URL: https://www.kmu.gov.ua/npas/prozatverdzhennya-poryadkiv-z-pita-a1165 (дата звернення: 18.01.2021). 


\section{ЮРИДИЧНА ПРАКТИКА У СФЕРІ АДМІНІСТРАТИВНОГО ПРАВА ТА ПРОЦЕСУ}

20. Про затвердження Порядку прийняття рішень про реєстрацію/відмову в реєстрації податкових накладних/розрахунків коригування в Єдиному реєстрі податкових накладних : Наказ Міністерства фінансів України від 12.12.2019 p. № 520. URL: https://zakon.rada.gov.ua/ laws/show/z1245-19 (дата звернення: 15.12.2020).

21. Проценко Т.О. Правове регулювання адміністрування податків і митних платежів : дис.... докт. юрид. наук : 12.00.07. Київ, 2007. 390 с.

22. Постанова Верховного Суду України від 28.08.2018 р. у справі № 820/20188/14. URL: http://reyestr.court.gov.ua/Review/76138136 (дата звернення: 12.12.2020).

23. Постанова Верховного Суду України від 16.04.2019 р. у справі № 804/5465/16. URL: http://reyestr.court.gov.ua/Review/81182457 (дата звернення: 12.12.2020).

24. Постанова Верховного Суду України від 11.06.2019 р. у справі № 825/2387/18. URL: http://reyestr.court.gov.ua/Review/82349303 (дата звернення: 13.12.2020).

25. Стиглиц Дж.Ю. Экономика государственного сектора. Москва : Изд-во МГУ: ИНФРА-М, 1997. 720 c.

26. The Fiscalis 2020 Programme. URL: https://ec.europa.eu/taxation_customs/fiscalisprogramme_en. (дата звернення: 14.12.2020).

27. VIES (VAT Information Exchange System) enquiries. URL: https://ec.europa.eu/taxation customs/business/vat/eu-vat-rules-topic/vies-vat-information-exchange-system-enquiries_en. (дата звернення: 14.12.2020).

\section{References:}

1. Andriushchenko, I., Hryn, Yu. (2015). Mizhnarodnyi dosvid orhanizatsii podatkovoho administruvannia [International experience of organization of tax administration]. Efektyvna ekonomika, No. 11. Retrieved from: http://nbuv.gov.ua/UJRN/efek_2015_11_42 [in Ukrainian].

2. Bandurka, O. (2004). Administratyvne pravo Ukrainy: pidruchnyk [Administrative law of Ukraine: textbook]. Kharkiv. Vydavnytstvo Natsionalnoho universytetu vnutrishnikh sprav, p. 480 [in Ukrainian].

3. Bytiak, Yu., Harashchuk, V., Diachenko, O. ta in. (2005). Administratyvne pravo Ukrainy: pidruchnyk [Administrative law of Ukraine: textbook]. Kyiv. Yurinkom Inter, pp. 170-202 [in Ukrainian].

4. Holovach, A. (2004). Zakhody administratyvnoho prymusu, ne poviazani z vidpovidalnistiu, v diialnosti orhaniv derzhavnoi podatkovoi sluzhby Ukrainy: pytannia teorii ta praktyky: avtoreferat dysertatsii kand. yurydychnykh nauk: 12.00.07 [Measures of administrative compulsion, unrelated to liability, in the activity of the bodies of the state tax service of Ukraine: problems of theory and practice: author's abstract of thesis for degree of cand. of legal sciences: 12.00.07]. Irpin. Natsionalnyi universytet derzhavnoi podatkovoi sluzhby Ukrainy, p. 19 [in Ukrainian].

5. Holosnichenko, I. (2007). Perspektyvni polozhennia kodyfikatsii norm pravovoho instytutu administratyvnoi vidpovidalnosti [Perspective provisions of codification of the norms of legal institution of administrative liability]. Pravo Ukrainy, No. 7, pp. 60-63 [in Ukrainian].

6. Kolpakov, V. (2004). Administratyvno-deliktnyi pravovyi fenomen: monohrafiia [Administrative and delict legal phenomenon: monograph]. Kyiv. Yurinkom Inter, p. 528 [in Ukrainian].

7. Matselyk, T. (2005). Administratyvnyi prymus v diialnosti orhaniv derzhavnoi podatkovoi sluzhby Ukrainy: avtoreferat dysertatsii ... stupenia kand. yurydychnykh nauk: 12.00.07 [Administrative compulsion in the activity of the bodies of the state tax service of Ukraine: author's abstract of thesis... for degree of cand. of legal sciences: 12.00.07]. Irpin, p. 17 [in Ukrainian].

8. Nakaz pro zatverdzhennia Poriadku pryiniattia rishen pro reiestratsiiu/vidmovu v reiestratsii podatkovykh nakladnykh/rozrakhunkiv koryhuvannia $\mathrm{v}$ Yedynomu reiestri podatkovykh 
nakladnykh, 2019 (Ministerstvo finansiv Ukrainy) [Order on approval of the Procedure of making decisions on registration/rejection to register invoices/adjustment calculations in the Unified register of tax, 2019 (Ministry of finance of Ukraine). Ofitsiynyy sayt Verkhovnoyi Rady Ukrayiny. Retrieved from: https://zakon.rada.gov.ua/laws/show/z1245-19 [in Ukrainian].

9. Podatkovi pryntsypy Dzhozefa Stihlitsa [Taxation principles of Joseph Stiglitz]. Retrieved from: https://pidruchniki.com/12041005/finansi/podatkovi_printsipi_dzhozefa_ stiglitsa [in Ukrainian].

10. Podatkovyi kodeks Ukrainy, 2010 (Verkhovna Rada Ukrainy) [Tax Code of Ukraine, 2010 (Verkhovna Rada of Ukraine)]. Ofitsiynyy sayt Verkhovnoyi Rady Ukrayiny. Retrieved from: http://zakon5.rada.gov.ua/laws/show/2755-17\#Text [in Ukrainian].

11. Postanova pro zatverdzhennia poriadkiv $\mathrm{z}$ pytan zupynennia reiestratsii podatkovoi nakladnoi/rozrakhunku koryhuvannia $\mathrm{v}$ Yedynomu reiestri podatkovykh nakladnykh, 2018 (Kabinet Ministriv Ukrainy) [Resolution on approval of Procedures on issues of suspension of registration of a tax invoice/adjustment calculation in the Unified Register of tax invoices, 2018 (Cabinet of Ministers of Ukraine)]. Ofitsiynyy sayt Verkhovnoyi Rady Ukrayiny. Retrieved from: https://zakon.rada.gov.ua/laws/show/117-2018-\%D0\%BF\#Text [in Ukrainian].

12. Postanova pro zatverdzhennia poriadkiv $\mathrm{z}$ pytan zupynennia reiestratsii podatkovoi nakladnoi/rozrakhunku koryhuvannia $\mathrm{v}$ Yedynomu reiestri podatkovykh nakladnykh, 2019 (Kabinet Ministriv Ukrainy) [Resolution on approval of Procedures on issues of suspension of registration of a tax invoice/adjustment calculation in the Unified Register of tax invoices, 2019 (Cabinet of Ministers of Ukraine)]. Ofitsiynyy sayt Verkhovnoyi Rady Ukrayiny. Retrieved from: https://zakon.rada.gov.ua/laws/show/1165-2019-\%D0\%BF\#Text [in Ukrainian].

13. Postanova po spravi No. 804/5465/16, 2019 (Verkhovnyi Sud Ukrainy) [Resolution on case No. 804/5465/16, 2019 (Supreme Court of Ukraine)]. Yedynyi derzhavnyi reiestr sudovykh rishen. Retrieved from: http://reyestr.court.gov.ua/Review/81182457 [in Ukrainian].

14. Postanova po spravi No. 825/2387/18, 2019 (Verkhovnyi Sud Ukrainy) [Resolution on case No. 825/2387/18, 2019 (Supreme Court of Ukraine)]. Yedynyi derzhavnyi reiestr sudovykh rishen. Retrieved from: http://reyestr.court.gov.ua/Review/82349303 [in Ukrainian].

15. Postanova po spravi No. 820/20188/14, 2018 (Verkhovnyi Sud Ukrainy) [Resolution on case No. 820/20188/14, 2018 (Supreme Court of Ukraine)]. Yedynyi derzhavnyi reiestr sudovykh rishen. Retrieved from: http://reyestr.court.gov.ua/Review/76138136 [in Ukrainian].

16. Protsenko, T. (2007). Pravove rehuliuvannia administruvannia podatkiv i mytnykh platezhiv: dys. ... dokt. yuryd. nauk: 12.00.07 [Legal regulation of tax and customs fees administration: dis. .... doct. of law: 12.00.07]. Kyiv, p. 390 [in Ukrainian].

17. Stiglicz, Dzh. (1997). Ekonomika gosudarstvennogo sektora [Public sector economy]. Moskva. Izdatel'stvo MGU: INFRA-M, p. 720 [in Russian].

18. Tymoshchuk, V. (2003). Administratyvna protsedura ta administratyvni posluhy. Zarubizhnyi dosvid i propozytsii dlia Ukrainy [Administrative procedure and administrative services. International experience and proposals for Ukraine]. Kyiv: Fakt, p. 496 [in Ukrainian].

19. The Fiscalis 2020 Programme. Retrieved from: https://ec.europa.eu/taxation_customs/ fiscalis-programme_en [in English].

20. VIES (VAT Information Exchange System) enquiries. Retrieved from: https://ec.europa.eu/ taxation_customs/business/vat/eu-vat-rules-topic/vies-vat-information-exchange-systemenquiries_en [in English].

21. Vsesvitnii slovnyk ukrainskoi movy, 2020 [Worldwide dictionary of the Ukrainian, 2020]. Retrieved from: https://uk.worldwidedictionary.org [in Ukrainian].

22. Yedynyi derzhavnyi reiestr sudovykh rishen, 2020 [Unified state register of court resolutions, 2020]. Retrieved from: http://reyestr.court.gov.ua [in Ukrainian]. 


\title{
ЮРИДИЧНА ПРАКТИКА У СФЕРІ АДМІНІСТРАТИВНОГО ПРАВА ТА ПРОЦЕСУ
}

23. Zvit Derzhavnoi fiskalnoi sluzhby Ukrainy za 2017, 2018 [Report of the State fiscal service of Ukraine for 2017, 2018]. Ofitsiinyi vebsait Derzhavnoi fiskalnoi sluzhby Ukrainy. Retrieved from: http://sfs.gov.ua/data/files/223549.PDF [in Ukrainian].

24. Zvit Derzhavnoi fiskalnoi sluzhby Ukrainy za 2018, 2019 [Report of the State fiscal service of Ukraine for 2018, 2019]. Ofitsiinyi vebsait Derzhavnoi fiskalnoi sluzhby Ukrainy. Retrieved from: http://sfs.gov.ua/data/files/240396.pdf [in Ukrainian].

25. Zvit sudiv pershoi instantsii pro rozghliad sprav u poriadku administratyvnoho sudochynstva za 2017 rik (forma No. 2-A), 2018 [Report of courts of first instance about judicial examination of cases in order of administrative proceedings for 2017 (form No. 2-A), 2018]. Ofitsiinyi vebsait Sudovoi vlady Ukrainy. Retrieved from: https:/court.gov.ua/inshe/sudova statystyka/rik_2017 [in Ukrainian].

26. Zvit sudiv pershoi instantsii pro rozghliad sprav u poriadku administratyvnoho sudochynstva za 2018 rik (forma No. 1-A), 2019 [Report of courts of first instance about judicial examination of cases in order of administrative proceedings for 2018 (form No. 1-A), 2019]. Ofitsiinyi vebsait Sudovoi vlady Ukrainy. Retrieved from: https:/court.gov.ua/inshe/sudova statystyka/rik_2018 [in Ukrainian].

27.Zvit sudiv pershoi instantsii pro rozghliad sprav u poriadku administratyvnoho sudochynstva za 2019 rik, 2020 [Report of courts of first instance about judicial examination of cases in order of administrative proceedings for 2019 (form No. 1-A), 2020]. Ofitsiinyi vebsait Sudovoi vlady Ukrainy. Retrieved from: https://court.gov.ua/inshe/sudova_statystyka/rik_2019 [in Ukrainian].

\section{ОСОБЛИВОСТІ ЗАБЕЗПЕЧЕННЯ ДОТРИМАННЯ ЗАКОННОСТІ У СФЕРІ АДМІНІСТРУВАННЯ ПДВ}

\author{
Андрій Логвин, \\ доктор філософії з права \\ orcid.org/0000-0003-4373-375X \\ logvin.andrey80@gmail.com
}

Автором досліджено правове регулювання протидї ухиленню від сплати податку на додану вартість (уникнення від виконання платниками податків свого податкового обов'язку шляхом мінімізації податкових зобов'язань), щзо є специфічним видом діяльності органів податкової служби у сфері оподаткування. Постійний розвиток суспільних відносин у сфері оподаткування в Україні, зокрема запровадження електронного адміністрування податку на додану вартість, вимагає ефективного застосування заходів адміністративного запобігання (протидіï) правопорушенням у иій сфері та, звісно, якісного стану правового регулювання вказаних заходів. У юридичній літературі заходи адміністративного запобігання здебільшого досліджувались з точки зору понятійно-категорійного апарату та їх класифікації. Натепер з урахуванням запровадження електронного адміністрування податку на додану вартість дослідження питань застосування суб'єктами владних повноважень заходів адміністративного запобігання в науковій сфері не проводились. 3 огляду на міжнародний досвід та на основі системного аналізу норм чинного законодавства досліджено правовий механізм протидії ухиленню від сплати податку на додану вартість, з урахуванням запровадження електронного адміністрування податку на додану вартість та моніторингу відповідності податкових накладних/ розрахунків коригування критеріям оцінки ступеня ризиків. Автором зазначається, щьо із 
ЮРИДИЧНА ПРАКТИКА У СФЕРІ АДМІНІСТРАТИВНОГО ПРАВА ТА ПРОЦЕСУ

запровадженням автоматизованого моніторингу оиінки ризиків (урахуванням критерію щцодо суми сплаченого податку на додану вартість (так зване «податкове навантаження» або «податкова віддача»)) держава намагається підвищити надходження до бюджету. Зазначене також створює умови для використання схем маніпулювання податковими зобов'язаннями та податковим кредитом недобросовісними підприємствами (дотримуючись певних умов). За наслідками дослідження автор доходить висновку, щио заходи адміністративної профілактики (протидіi), щзо застосовуються контролюючими органами, є в певному сенсі інструментами, за допомогою яких забезпечується можливість своєчасної реакиії на діяльність платників податків, спрямовану на ухилення від сплати податків. Аргументовано, щчо автоматизований моніторинг відповідності податкових накладних/розрахунків коригування критеріям оцінки ступеня ризиків, який є складником електронного адміністрування податку на додану вартість, може розглядатись як захід запобігання (протидіï) ухиленню від сплати податку на додану вартість. Доведено, що з правової точки зору правовий механізм заходів адміністративного запобігання (протидії), зокрема щодо здійснення автоматизованого моніторингу, повинен спонукати уникнення правових колізій та суперечностей, які виникають між контролюючими органами та платниками податків.

Ключові слова: податок на додану вартість (ПДВ), система електронного адміністрування ПДВ, автоматизований моніторинг критеріїв оцінки ступеня ризиків, зупинка реєстрації податкових накладних/розрахунків коригування. 